\title{
Cloudina-Corumbella-Namacalathus association from the Itapucumi Group, Paraguay: Increasing ecosystem complexity and tiering at the end of the Ediacaran
}

\author{
Lucas Veríssimo Warren ${ }^{\mathrm{a}, *}$, Fernanda Quaglio ${ }^{\mathrm{b}}$, Marcello Guimarães Simões ${ }^{\mathrm{c}}$, Claudio Gaucher ${ }^{\mathrm{d}}$, \\ Claudio Riccomini ${ }^{\mathrm{e}}$, Daniel G. Poiré ${ }^{\mathrm{f}}$, Bernardo Tavares Freitas ${ }^{\mathrm{g}}$, Paulo C. Boggiani ${ }^{\mathrm{h}}$, Alcides Nobrega Sial ${ }^{\mathrm{i}}$ \\ a Departamento de Geologia Aplicada, Instituto de Geociências e Ciências Exatas, Universidade Estadual Paulista, Avenida 24A, 1515, Rio Claro 13506-900, Brazil \\ ${ }^{\mathrm{b}}$ Curso de Geologia, Instituto de Geografia, Universidade Federal de Uberlândia, Rodovia LMG 746, Km 1, Monte Carmelo 38500-000, Brazil \\ c Departamento de Zoologia, Instituto de Biociências, Universidade Estadual Paulista, Distrito de Rubião Júnior, Botucatu 18618-000, Brazil \\ dinstituto de Ciencias Geológicas, Facultad de Ciencias, Iguá 4225, Montevideo 11400, Uruguay \\ e Instituto de Energia e Ambiente, Universidade de São Paulo, Avenida Professor Avenida Luciano Gualberto, 1289, São Paulo 05508-010, Brazil \\ ${ }^{\mathrm{f}}$ Centro de Investigaciones Geológicas, UNLP-CONICET, calle 1, n. 644, La Plata 1900, Argentina \\ ${ }^{\mathrm{g}}$ Faculdade de Tecnologia, Universidade Estadual de Campinas, R. Paschoal Marmo, 1888, Limeira 13484-332, Brazil \\ ${ }^{\mathrm{h}}$ Instituto de Geociências, Universidade de São Paulo, Rua do Lago, 562, São Paulo 05508-080, Brazil \\ ${ }^{i}$ NEG-LABISE, Department of Geology, Universidade Federal de Pernambuco, Av. Acadêmico Hélio Ramos, Recife 7852, Brazil
}

\section{A R T I C L E I N F O}

Article history:

Received 2 February 2017

Revised 15 May 2017

Accepted 21 May 2017

Available online 22 May 2017

\section{Keywords:}

Namacalathus

Ediacaran

Itapucumi Group

Paleoecology

Paleogeography

Clymene Ocean

\begin{abstract}
A B S T R A C T
The intriguing Ediacaran fossil Namacalathus is described from limestones of the Tagatiya Guazú Formation, Itapucumi Group, Paraguay. This is the fifth occurrence of the genus in the Ediacaran geological record. The Paraguayan Namacalathus specimens are preserved as partially complete spheroidal cups with an opening at the top and thin walled stems. The remains of this soft-calcified globe-shaped organism occur as sparse disarticulated parautochthonous fragments within bioclastic deposits dominated by Cloudina shells with subordinate Corumbella fragments. The co-occurrence of these three skeletal metazoan species in the same environmental context attests that the diversity of the Paraguayan accumulations is ecologically comparable to the typical skeletal assemblage of the Nama Group. The discovery of new samples of Namacalathus in the Itapucumi Group also indicates that this genus presented a broader paleobiogeographic distribution than previously thought and, in the same way as Cloudina, it represents a low latitude, shallow water metazoan of the Ediacaran Gondwana.
\end{abstract}

(c) 2017 Elsevier B.V. All rights reserved.

\section{Introduction}

Early diversification of a variety of biomineralized organisms, including metazoans such as Cloudina, conulariids, Namacalathus, Namapoikia, Sinotubulites (see Grotzinger et al., 2000; Gaucher and Germs, 2009; Wood et al., 2002; Van Iten et al., 2014) in the latest Ediacaran was accompanied by colonization of new habitats, competition for substrate, predation/trophic escalation and increase in ecologic complexity of marine ecosystems (Bengtson, 2002; Wood, 2011; Wood and Curtis, 2014; Penny et al., 2016). The appearance of these metazoans bearing skeletons seems to be an adaptation (or exaptation) to the increasing predation pressure (Bengtson, 1994, 2004; Knoll, 2003; Wood, 2011; Wood and

\footnotetext{
* Corresponding author.

E-mail address: warren@rc.unesp.br (L.V. Warren).
}

Zhuravlev, 2012), to variation in the ocean chemistry (Lowenstam and Weiner, 1989) or as a mechanism to enhance feeding efficiency and conquer new niches (Wood, 2011). However, the association of organic-walled metazoan Corumbella and calcite shelled Cloudina suggests that the process of biomineralization and secretion of organic walls occurred synchronously at the terminal Ediacaran (Warren et al., 2012). This may support the hypothesis that the acquisition of biomineralized hard parts was primarily promoted by ecological forces than fluctuations in ocean chemistry (Hua et al., 2007). On the other hand, recent evidence suggests that the transition from aragonite-dolomite seas to aragonite seas after 545 Ma facilitated the acquisition of hard parts by metazoans, coupled with more widespread oxic conditions (Wood et al., 2016). Aside the composition of these first skeletons (aragonite and high-Mg calcite skeletons), the presence of biomineralized hard parts also affected sedimentary dynamics, especially architec- 
ture of carbonate platforms in marine environments (Warren et al., 2012). Indeed, the production of exoskeletons promoted an unprecedented autochthonous input of biogenic hard parts into previously bioclast-free shallow marine environments (Pratt, 1982; Warren et al., 2013). The interaction of these particles and the substrate led to the formation of bioclastic-rich deposits providing stable and rigid substrates for the establishment and growth of metazoan communities (Wood, 2011).

Namacalathus ( $550-541 \mathrm{Ma})$ is a problematic and morphologically unique Ediacaran metazoan, characterized by a thin-walled, stalked, goblet-shaped theca (the cup diameter is up to $35 \mathrm{~mm}$ ) (Grotzinger et al., 2000; Wood, 2011; Vinn and Zatón, 2012). Detailed morphological reconstructions provided by Grotzinger et al. (2000), on the basis of specimens from the Nama Group (Namibia), indicate that the goblet has a hole in the upper portion and various (six or seven) large symmetrical lateral lacunae (see also Wood and Curtis, 2014). The theca was made of high-Mg calcite or aragonite minerals (Grotzinger et al., 2000; Zhuravlev and Wood, 2008). The phylogenetic affinities of Namacalathus are uncertain, as they may represent stem- or crown-group cnidarians (Grotzinger et al., 2000; Wood and Curtis, 2014) or even a lophophorate (Zhuravlev et al., 2015). The exoskeleton of Namacalathus comprises a triple-layered structure, including an inner foliated layer with columnar microlamellar inflections, an internal (middle) organic rich layer and a foliated external outer layer (Zhuravlev et al., 2015). Dolomite microcrystals within the thicker inner layer indicate that it initially comprised high-Mg composition, suggesting an accretionary style of skeletal growth and affinity with the Lophotrochozoa, especially with Brachiopoda and Bryozoa, as well as an internal budding expressed in a symmetrical, bilateral pattern (Zhuravlev et al., 2015). However, Namacalathus appears to have a hexaradial symmetry, an apparent problem to the interpretation suggested by Zhuravlev et al. (2015).

Namacalathus was a benthic, epifaunal, organism that thrived mainly in shallow marine, carbonate-dominated ecosystems, including: (a) thrombolitic reefs (Namibia, Canada, and Oman) and (b) shallow to deep (inner to mid ramp) carbonate platforms (Namibia, Russia) (see Grotzinger et al., 2000; Watters et al., 2000; Hofmann and Mountjoy, 2001; Amthor et al., 2003; Wood, 2011; Wood and Curtis, 2014; Penny et al., 2016). Namacalathus is also known from carbonates in Russia (Kontorovich et al., 2008), but their ecology and mode of occurrence were not studied in detail.

Recent analysis of in situ Namacalathus-rich assemblages from the Nama Group, suggest that this metazoan exhibited size variation in response to differing water depths, hydrodynamic conditions and substrate types (Penny et al., 2016). These authors noted that inner ramp monospecific aggregations of large Namacalathus are recorded in microbially-bounded micritic substrates. While in mid-ramp reef settings large Namacalathus with various cup diameters and long stems are associated with thrombolites, in outer ramp settings, individuals form small patchy, dense, monospecific aggregations in thin mat-dominated substrates locally occupying scours produced by periodic storms (Penny et al., 2016).

Although a possible occurrence of Namacalathus in the Itapucumí Group, Paraguay, was previously envisaged by Gaucher and Germs (2009), the record of this widespread, Ediacaran skeletal metazoan in Neoproterozoic Paraguay is unprecedented. Therefore, in this contribution a novel occurrence of Namacalathus is recorded in this unit. In addition, new polyspecific association of Namacalathus, Cloudina and Corumbella is described, placing the paleoecology of these Ediacaran biomineralized metazoans within a paleoenvironmental context. Data here conclusively indicate that these skeletal metazoans colonized previously unoccupied substrates in microbial-dominated carbonate settings, forming a relatively "diverse" community.

\section{Geological setting}

In northeastern Paraguay, the 400-m-thick carbonate succession of the Itapucumí Group crops out near the Paraguay River margins. The unit occurs in erosional contact upon the Paleoproterozoic basement of the Río Apa Block (Fig. 1A) and is subdivided in two structural domains, the Vallemí Fold Belt to the west and the cratonic cover to the east (Campanha et al., 2010). The western sedimentary succession is composed of sandstones and siltstones of the Vallemí Formation that grades to oolitic limestones and dolostones of the Camba Jhopo Formation, and marls and shales of the Cerro Curuzú Formation (Fig. 1B). The undeformed and unmetamorphosed carbonate unit in the east is known as Tagatiyá Guazú Formation, a $120-\mathrm{m}$ thick succession, which is laterally equivalent to the Camba Jhopo Formation (Warren, 2011). The lower part of the Tagatiyá Guazú Formation (Fig. 1C) consists of a 30-m thick succession of non-dolomitized carbonate facies, including breccias, grainstones with tidal bundles and wave ripples, heterolithic laminations and microbialites (Fig. 2A-D). The tidally influenced sedimentary facies and the presence of salt pseudomorphs, tepees and desiccation cracks suggest deposition in a very shallow peritidal environment under evaporitic conditions (Warren et al., 2011). The microbialite facies are composed of flat microbial mats, oncolites and thrombolites that form meter-scale biostromes with a lateral extension of tens of meters. These biostromes are made up of laterally extensive, relatively low thrombolitic domes and irregular forms up to $10 \mathrm{~cm}$ in height, with inter-dome space filled by microbial limestone intraclasts (Fig. 2B-D).

The Ediacaran skeletal fossils occur in close association with microbialite facies, as bioclastic accumulations or in situ specimens attached to the thrombolitic domes (Warren et al., 2011, 2013). Cloudina is the most abundant epibenthic species of the assemblages (Fig. 3A and B), and is associated with fragmented carapaces of Corumbella werneri (Fig. 3C) and rare ichnofossils (Fig. 3D). These traces are horizontal bilobed trails preserved in positive epirelief characterized by two raised lobes separated by a central depression and are similar to Archaeonassa (Warren et al., 2011). The dense accumulations of Cloudina shells form highly aggregating clusters within the trough between thrombolitic domes, similar to those described by Wood et al. (2017) in the Nama Group, Namibia. All the specimens of Namacalathus occur in bioclastic shell beds dominated by fragmented and disarticulated Cloudina individuals (Fig. 3E, F and G).

\section{Taphonomy of Namacalathus in the late Ediacaran of Paraguay}

In the lower succession of the Tagatiyá Guazú Formation, the Namacalathus specimens are recorded in close association with thrombolites and microbial mats (Fig. 1C). These are found in at least two stratigraphic levels (Fig. 1C). As mentioned above, the densely packed bioclastic deposits are mainly composed of autochthonous to parautochthonous shells of Cloudina, which are associated with sparse Namacalathus individuals (Fig. 3E, F and G). An ordinary statistical analysis based in the counts and identification (simple average) of about 1000 specimens of skeletal organisms performed in these concentrations, revealed that at least $92 \%$ of the bioclasts are composed of Cloudina shells, 7\% are remains of stalks and cups of Namacalathus skeletons and less than $1 \%$ are fragments of Corumbella carapace. Some dense accumulations of Cloudina show complete in situ specimens with distinct shell sizes, suggesting individuals in different ontogenetic stages. Complete specimens of Namacalathus comprising articulated stalk and cup are very rare and restricted to small, dispersed samples (Fig. $4 \mathrm{H}$ ). 

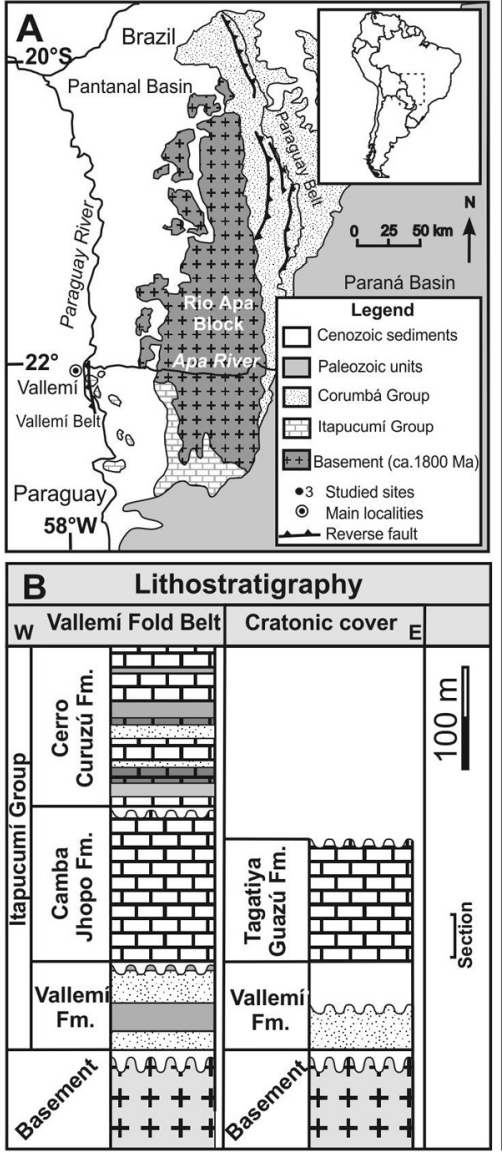

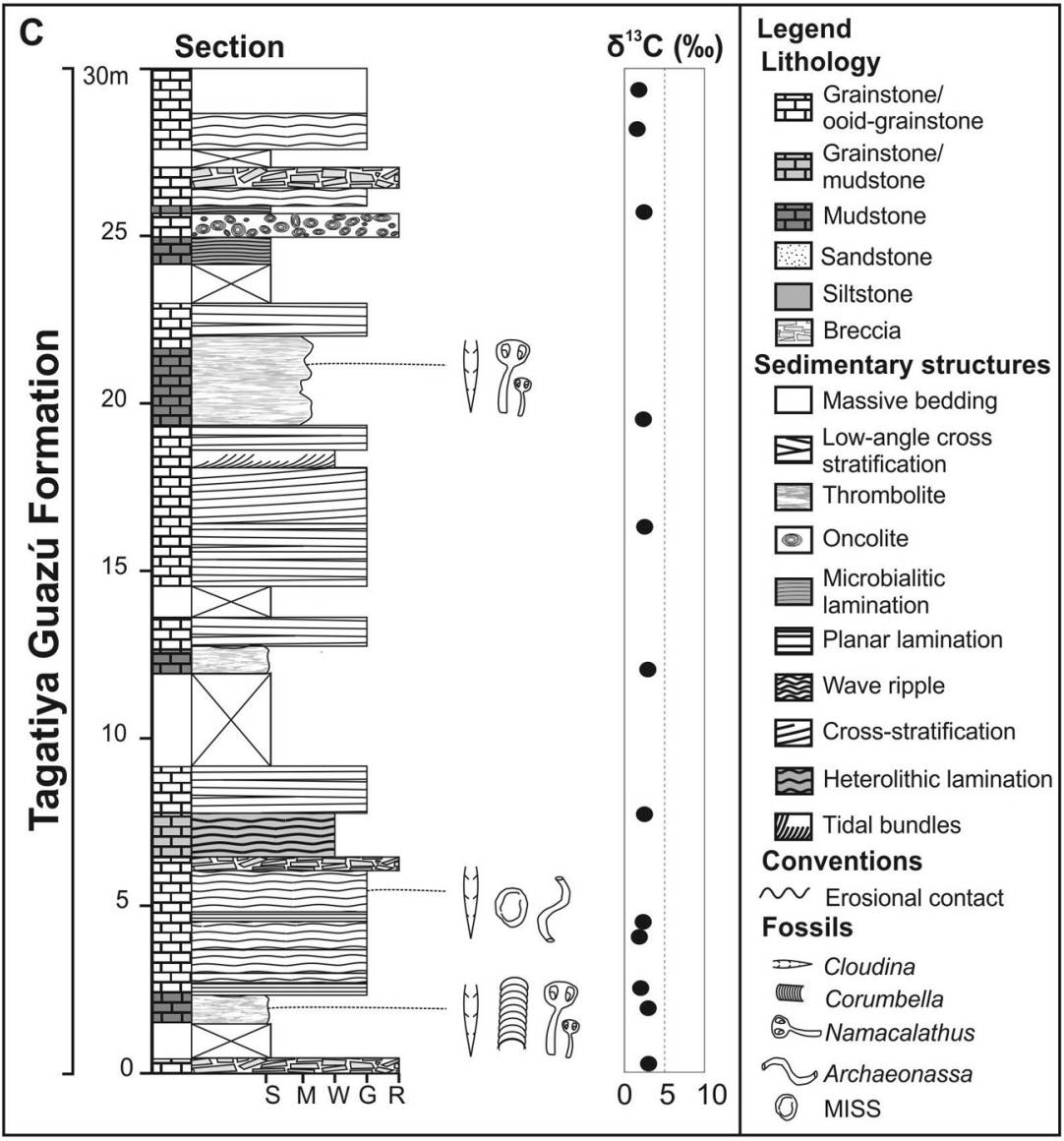

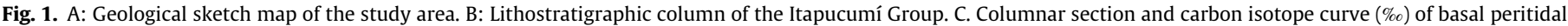

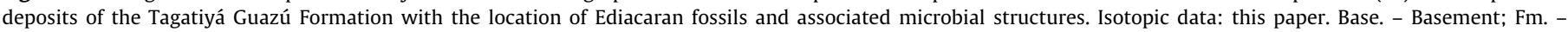

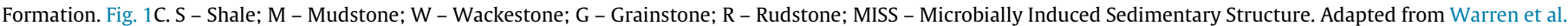
(2013).
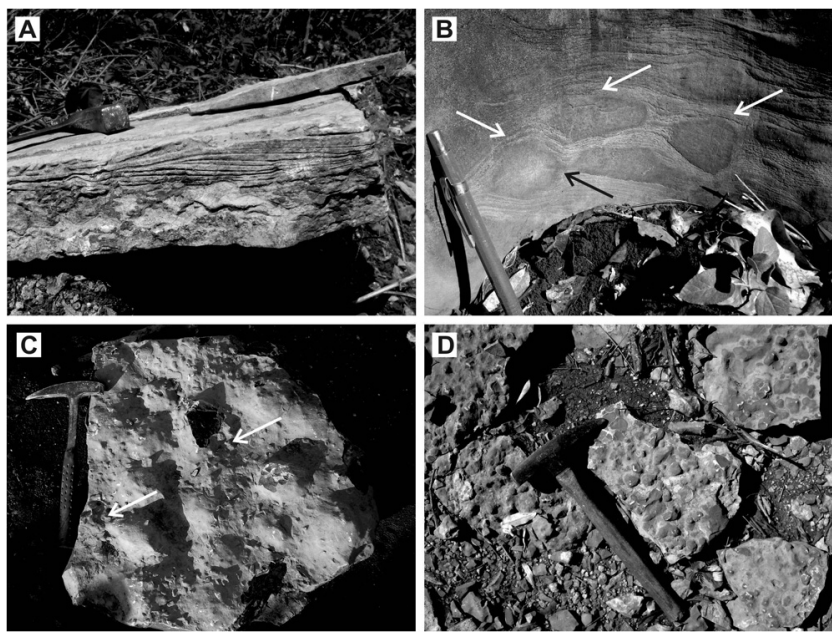

Fig. 2. A: Detail of grainstone with wave ripple cross lamination. B: Oncolites (white arrows) showing irregular microbial laminations and coalescent points (black arrow). C: Plan view of centimeter-size thrombolite domes. Note the small platy intraclasts and bioclastic concentrations between the elevations (white arrows). D: Close up of small irregular thrombolite domes.

Around $99 \%$ of the analyzed samples are stalk fragments as well as parts disconnected from the globet (Figs. 4A-M and $\mathrm{A}^{\prime}-\mathrm{M}^{\prime}$ ). The diagnostic hexagonal section (Grotzinger et al., 2000) is not well preserved, although some specimens may display it (see Fig. 4J and $\mathrm{J}^{\prime}$ ). In comparison to Cloudina individuals, the Namacalathus remains are much larger (Figs. 3D and $4 \mathrm{~A}-\mathrm{M}$ ) and fragmented. The walls of the stalks and cups of the Paraguayan Namacalathus are thinner than $100 \mu$ (generally not reaching $50 \mu$ ) and made up of calcite. Similarly to the Namibian specimens, most of the studied individuals (cup and stalk) are broken, suggesting that the skeleton was brittle and slightly mineralized (Fig. 4K) (see also Grotzinger et al., 2000). However, various specimens are also compressed due to compaction, indicating that the carapace of Namacalathus was also flexible, at least under diagenetic conditions.

Fragments of stalks have average length of $9 \mathrm{~mm}$, with samples varying between $6 \mathrm{~mm}$ and $17 \mathrm{~mm}$ (Fig. 4G and H). The average diameter of the basal cylindrical section of the stalks is $1 \mathrm{~mm}$. The Paraguayan Namacalathus is substantially larger than the Russian ones (Kontorovich et al., 2008) and smaller than those from Oman, Namibia and Canada (Grotzinger et al., 2000; Hofmann and Mountjoy, 2001; Amthor et al., 2003). The maximum diameter of the cups is $6 \mathrm{~mm}$ (average $\sim 4 \mathrm{~mm}$ ) and its length is $\sim 8 \mathrm{~mm}$ (Fig. 4D). Unlike the examples in Namibia, the goblets are not spheroidal and have a wider circular opening at the top, similar to the cup of a "lily flower" (Please see Fig. 4A and D). The lateral apertures (lumens) are only observed few specimen (Fig. 4E, $\mathrm{E}^{\prime}, \mathrm{I}^{\prime}$ and I), which apparently shows four orifices. At the upper aperture, the thin walls have a diagnostic subtle convolution in their apexes to the inner portion of the cup (Fig. 4A, D, F and M). There are no evidence of parental cups connected with the main stem by secondary stalks, such as those observed by Zhuravlev et al. (2015) 

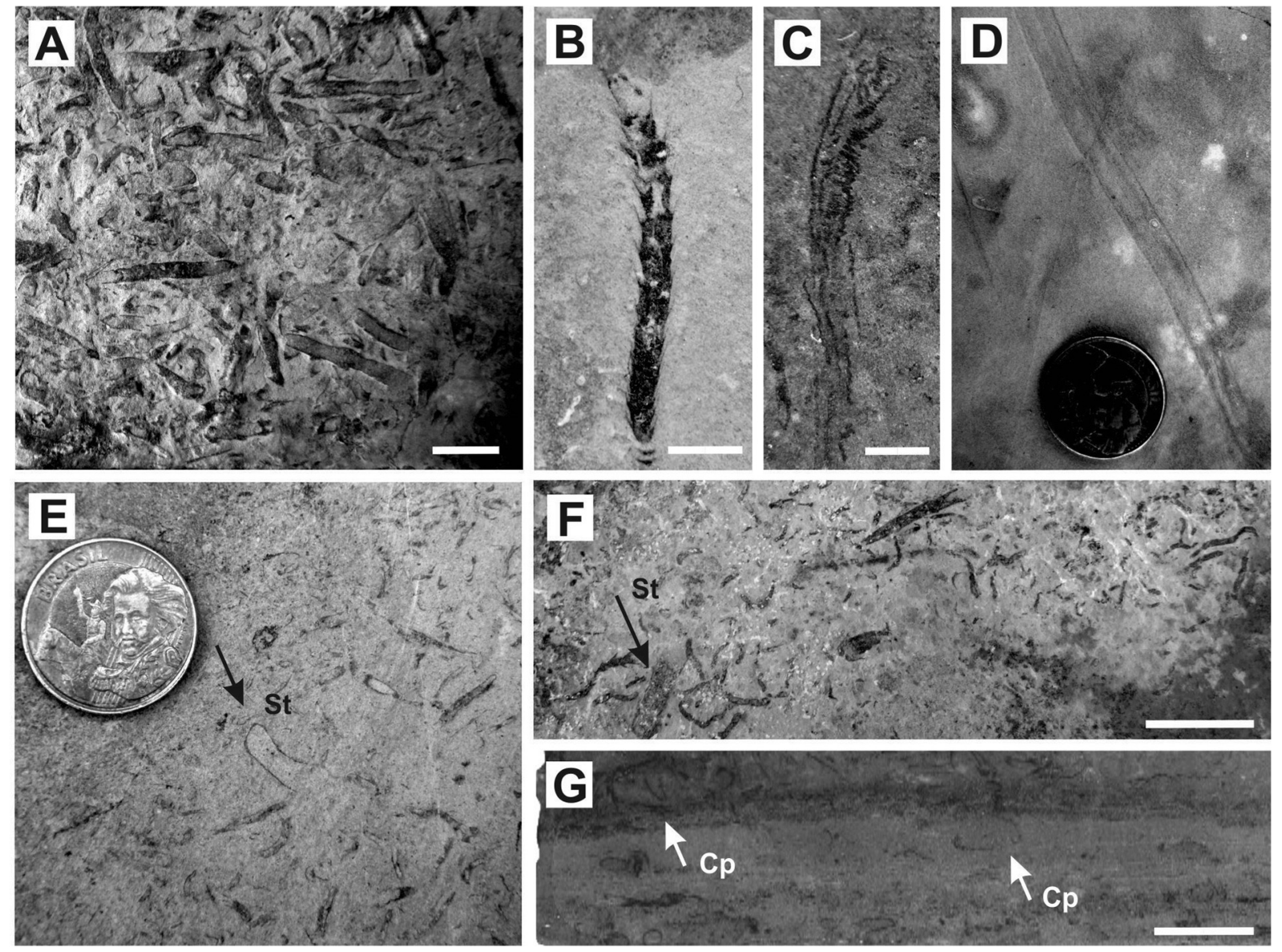

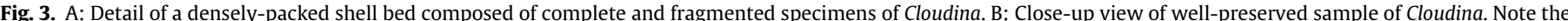

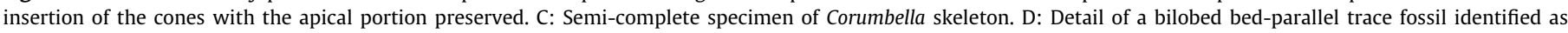

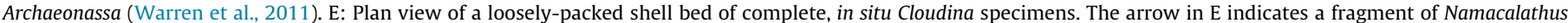

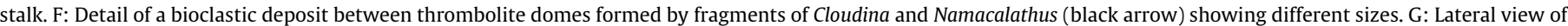

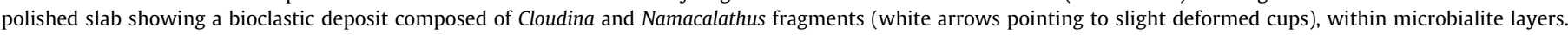
St = stem; Cp = cup. Scale bars = $1 \mathrm{~cm}$ in A and F; 0.25 in B and $0.5 \mathrm{~cm}$ in C and G. The coin in D and E is $1 \mathrm{~cm}$ in diameter.

in Namacalathus hermanastes from the Nama Group, Namibia. The Paraguayan specimens have their goblets filled by the same very fine grainstone that constitutes the host rock, suggesting that these cavities were originally empty. The stalks are occasionally filled by sparry calcite, indicating that the carapaces of the animal possibly blocked the infilling of the stalk by fine-grained sediment. Much after the final burial of the organism, diagenetic processes caused the interior portion of the stalks to be filled by sparry calcite cement, in the same way as in the co-occurring Cloudina specimens (Warren et al., 2011).

\section{Systematic paleontology}

Genus Namacalathus Grotzinger et al. (2000).

Type Species. Namacalathus hermanastes Grotzinger et al., 2000

Material: More than 40 specimens or fragments. The most representative is the individual in the Fig. 4B (VLM-86-C). Other representative specimens are observed in thin sections and polished rock slabs. Some samples, as the individuals in Figs. 4B, D, K and $\mathrm{L}$ are observed in slightly weathered slab surfaces.

Collection: Fossil specimens are hosted in the Department of Applied Geology of the São Paulo State University, Rio Claro, Brazil, with designation VLM-86-B, VLM-86-C, VLM-86-D, VLM-42-A and VLM-42-E.
Locality: Fossil localities are exposed along the Tagatiyá Guazú River and in the vicinities of the San Alfredo colony, Bello Horizonte and Santa María farms, Departamento de Concepción, Paraguay.

Facies and Stratigraphic Range: Microbialite facies of the peritidal carbonates of the Tagatiyá Guazú Formation, Itapucumí Group, Ediacaran of Paraguay.

Description: Namacalathus hermanastes from Paraguay is composed of a small goblet attached to a stem (Fig. 4B and $\mathrm{H}$ ). The cup resembles a lily flower and has apparently five (or six) lateral semicircular lumens. The most prominent aperture is localized in the apical portion of the goblet and is bordered by curled walls projected to the inner area of the gastrovascular cavity (Fig. 4D, F and M). Namacalathus hermanastes has length (goblet and cup) varying between 8 and $17 \mathrm{~mm}$. The maximum diameter of the cups reaches $8 \mathrm{~mm}$ close to the upper aperture (mean around $4 \mathrm{~mm}$ ). The stalks are cylindrical in shape with a diameter of about $1 \mathrm{~mm}$, length varying between $6 \mathrm{~mm}$ to $26 \mathrm{~mm}$ (mean of $6 \mathrm{~mm}$ ) and walls thinner than $100 \mu$ (generally not exceeding $50 \mu$ ). All goblets analyzed are filled by fine grainstone of the rock matrix, but stems may be filled by sparry calcite (Fig. 4G).

Remarks: Namacalathus hermanastes from Paraguay is smaller than specimens from Namibia and larger than specimens found in core samples in Siberia, Russia. The goblet of the Paraguayan specimens is not spheroidal and its shape resembles a lily-like cup with a big aperture at the top. The pronounced curvature of 

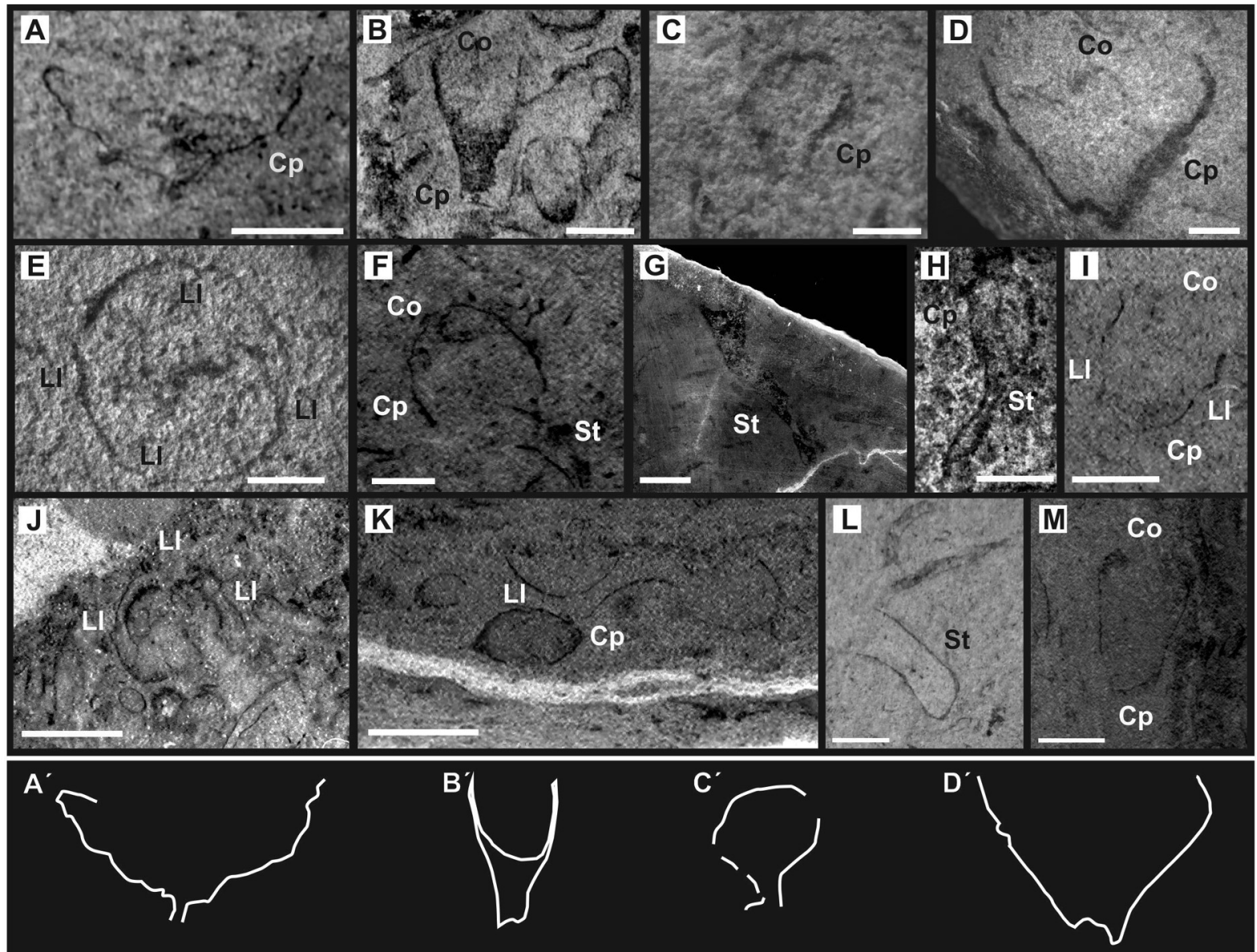

$E^{\prime}$

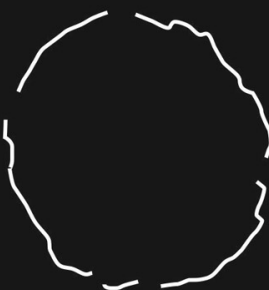

$J^{\prime}$

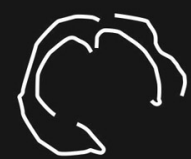

$\mathbf{F}$

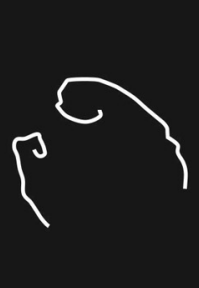

$\mathbf{G}^{\prime}$

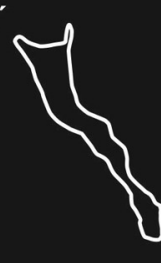

$H^{\prime}$

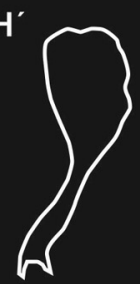

$L^{\prime}$

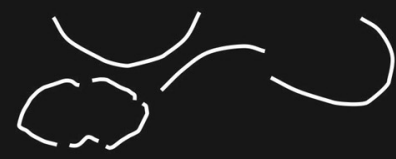

I'

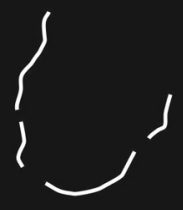

$\mathbf{M}^{\prime}$

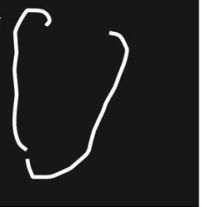

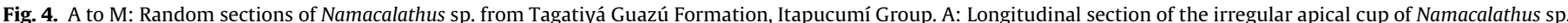

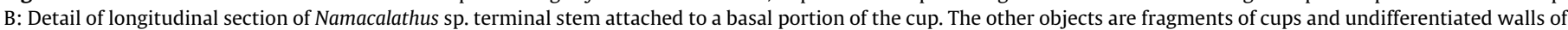

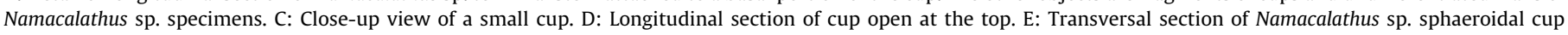

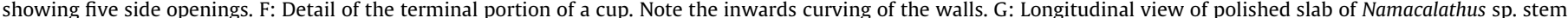

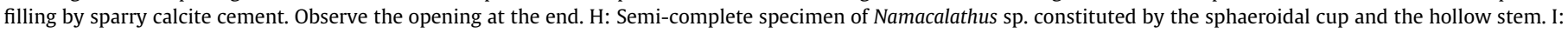

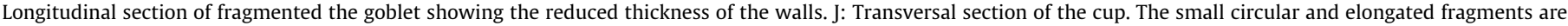

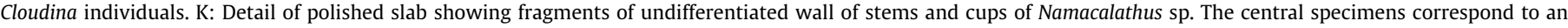

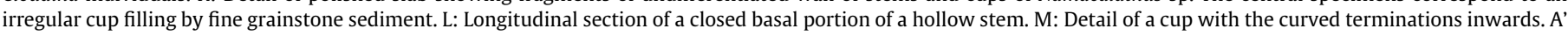

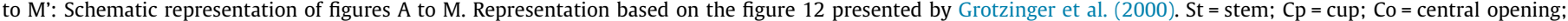
$\mathrm{Ll}=$ lateral lumen. Scale bars $=1 \mathrm{~cm}$ in $\mathrm{L} ; 4 \mathrm{~mm}$ in $\mathrm{K} ; 2 \mathrm{~mm}$ in $\mathrm{A}, \mathrm{B}, \mathrm{D}, \mathrm{E}, \mathrm{F}, \mathrm{G}, \mathrm{I}, \mathrm{J}$ and $\mathrm{M} ; 1 \mathrm{~mm}$ in $\mathrm{C}$ and $\mathrm{H}$.

the wall to the inner portion of the cup is another feature characteristic of Namacalathus from Namibia and Paraguay (Grotzinger et al., 2000). There are no evidences of parental cup in the described specimens from Paraguay. In addition, no primary organic-rich walls or organic remains are preserved in the Paraguayan specimens that could be comparable to those from Namibia described by Grotzinger et al. (2000) and Zhuravlev et al. (2015).

\section{Paleoautoecology of the Paraguayan Namacalathus hermanastes}

The Fig. 5 represents the reconstruction of living Paraguayan Namacalathus, based on the morphology described here and on works of Grotzinger et al. (2000), Hofmann and Mountjoy (2001) and Zhuravlev et al. (2015). Despite minor differences in the cup 


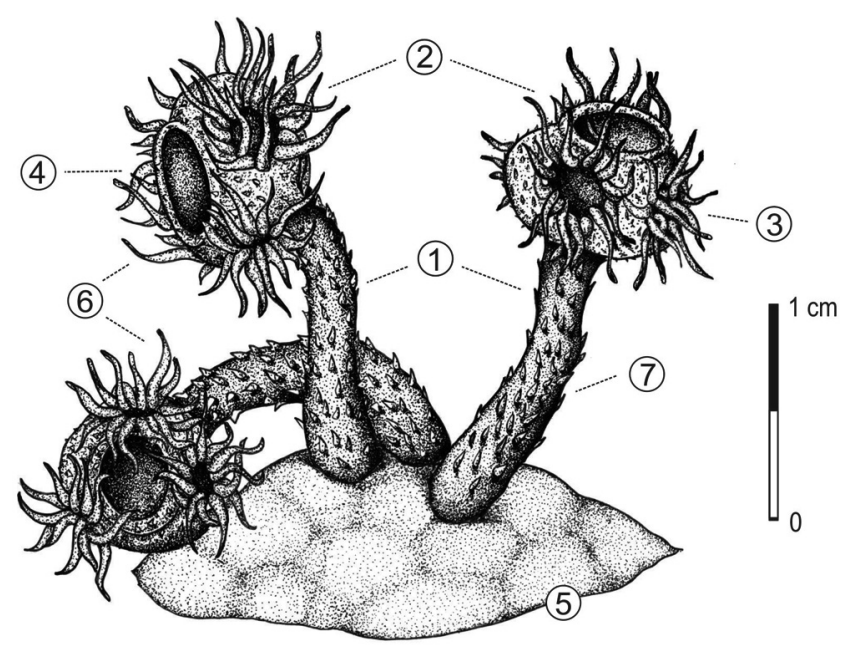

Fig. 5. Reconstruction of Namacalathus from Paraguay. This proposal is based in new data presented in this paper and works of Grotzinger et al. (2000), Hofmann and Mountjoy (2001) and, especially Zhuravlev et al. (2015). The basic morphology of Namacalathus are based in the tridimensional reconstruction of Grotzinger et al (2000). All external morphology in the Paraguayan Namacalathus, as ciliated tentacles and specially spines, are conjectural and supported by similarities with the Canadian and African specimens described by Hofmann and Mountjoy (2001) and Zhuravlev et al. (2015). The central opening is slightly wider than the represented in the reconstruction of Zhuravlev et al. (2015). 1 - stem; 2 - cup; 3 lateral lumen; 4 - central opening; 5 - thrombolite; 6 - ciliated tentacles; 7 spines. Image copyright: F.D.C Sales.

morphology, the Paraguayan specimens can be confidently assigned to Namacalathus hermanastes. As in the type material from Namibia, the goblet of Namacalathus from Paraguay also show an upper aperture opened into a gastrovascular cavity, possibly used for passive filtering of seawater. Cloudina and Corumbella are sessile organisms with possible cnidarian affinity (Vinn and Zatón, 2012; Pacheco et al., 2015), whereas Namacalathus is the first possible lophophorate in the geological record (Zhuravlev et al., 2015). However, these organisms thrived in the same environment, and may have had similar strategies for obtaining nutrients. The presence of oral apertures and flexible bodies indicate that these metazoans are passive predators (microcarnivores) or filter-feeders that feed on plankton or small nektonic organisms from the bottom currents (Babcock et al., 2005).

\section{Community structure - Namacalathus and the first metazoan reefs}

Recent advances in our knowledge about the genesis, structure and composition of the Ediacaran biostromes have shed light on the complex ecology of these first metazoan reefs. Cloudina was the first skeletal metazoan capable of promoting mutual attachment, to form complex, biogenic frameworks similar to that of early Paleozoic metazoan reefs (Penny et al., 2014; Wood and Curtis 2014). These appeared well before the advent of archaeocyathids and algae reefs, the main reef-builders of the Lower Cambrian (Debrenne, 2007). In the Ediacaran Nama Group, the reefs are formed as densely aggregated associations of Cloudina riemkeae with microbialites and thrombolites (Wood and Curtis, 2014). Cloudina and Namacalathus "also grow cryptically, either as pendent aggregations from laminar crypt ceilings in microbial framework reefs or as clusters associated with thrombolite attached to neptunian dyke walls" (Wood and Curtis 2014, p. 112, see also Penny et al., 2016).

Namacalathus, like Cloudina, probably had aggregating growth (Grotzinger et al., 2000; Wood, 2011; Penny et al., 2014, 2016;
Wood and Curtis, 2014) anchored within or attached to microbial mats (Zhuravlev et al., 2015; Penny et al., 2016). As in Namibian reefs (Penny et al., 2014), both genera occur in small clusters (Fig. 6) in the Paraguayan shallow carbonate platform. This strategy promoted the rise of Cloudina and Namacalathus above the substrate, which was advantageous for active nutrient acquisition and niche expansion (Wood, 2011). The construction of a hard, stable substrate also promoted the defense from waves and currents. In this context, organisms thriving in association with clusters of Cloudina and Namacalathus would have various environmental and ecological benefits (i.e., access to nutrients and protection). After the death of the skeletal metazoans the shells and carapaces of Cloudina, Namacalathus and Corumbella were concentrated in the low areas of the marine substrate between small elevations, as thrombolitic domes and troughs associated with bed forms (lowamplitude ripples) (Fig. 6, Warren et al., 2013). The early diagenetic cementation of the bioclastic deposits by primary sparry calcite cement precipitated around the bioclasts as a thin fringe was responsible for creating a rigid substrate on the seafloor and a new potential niche for colonization by other benthic invertebrates. Above the hard framework, the organisms can establish and grow, sometimes using new strategies as rapid growth rates and short life cycles (Wood, 2011). Apparently, the first metazoan reefs were populated, at least, by three skeletal organisms with cnidarian and lophophoratan affinity: Corumbella werneri (organic walled), Cloudina and Namacalathus (Fig. 6, Grotzinger et al., 2000; Babcock et al., 2005; Vinn and Zatón, 2012; Zhuravlev et al., 2015), respectively. Therefore, the tiering of this community was much more complex than previous realized.

The $\delta^{13} \mathrm{C}$ isotopic data for the microbialites and other peritidal facies of Tagatiya Guazu Formation is around 2.5\% (Fig. 1C) is coherent with the positive plateau associated with other Cloudina bearing successions worldwide (Grotzinger et al., 1995, 2000; Amthor et al., 2003; Zhou and Xiao, 2007; Gómez-Peral et al., 2007; Gaucher and Germs, 2009; Boggiani et al., 2010; Warren et al., 2011). The $\delta^{13} \mathrm{C}$ positive values also points to a deposition in protected or confined waters, as lagoons or saline embayments (Warren, 2011), with high concentration of organic matter or prone to high organic decomposition (Thunell et al., 1987). As mentioned above, the presence of salt pseudomorphs, tepees and desiccation cracks reinforces the idea that sedimentation took place in evaporitic conditions with periodic subaerial exposure. The incidence of tidally-influenced sedimentary facies, as tidal bundles and sand/mud pairs, is diagnostic of deposition in intertidal settings, such as observed in coeval successions in Namibia, Oman and Canada (Amthor et al., 2003; Grotzinger et al., 2000; Hofmann and Mountjoy, 2001; Penny et al., 2014). These evidences support that the Cloudina-Namacalathus assemblage (and Corumbella in the Paraguayan case) usually thrived in protected and shallow environments recurrently associated with microbialites, in a similar manner as recently described by Penny et al. (2016).

\section{Paleobiogeography - a warm water dweller and its potential biostratigraphic use}

Fossil localities on available Ediacaran paleogeographic reconstructions (see Trindade et al., 2006; Li et al., 2008; Tohver et al., 2012) indicate that Namacalathus has spread through several oceans and interior seas surrounding low latitude paleocontinents, such as Proto-Gondwana, Laurentia, Amazonia/Río Apa and Siberia paleocontinents (Fig. 7). Similarly to modern benthic cnidarians and some lophophorates, Cloudina and Namacalathus dispersion probably occurred by oceanic currents transporting planktonic larvae for long distances, which explains the vast paleobiogeographic distribution of these organisms. The occurrence of Namacalathus exclusively in 


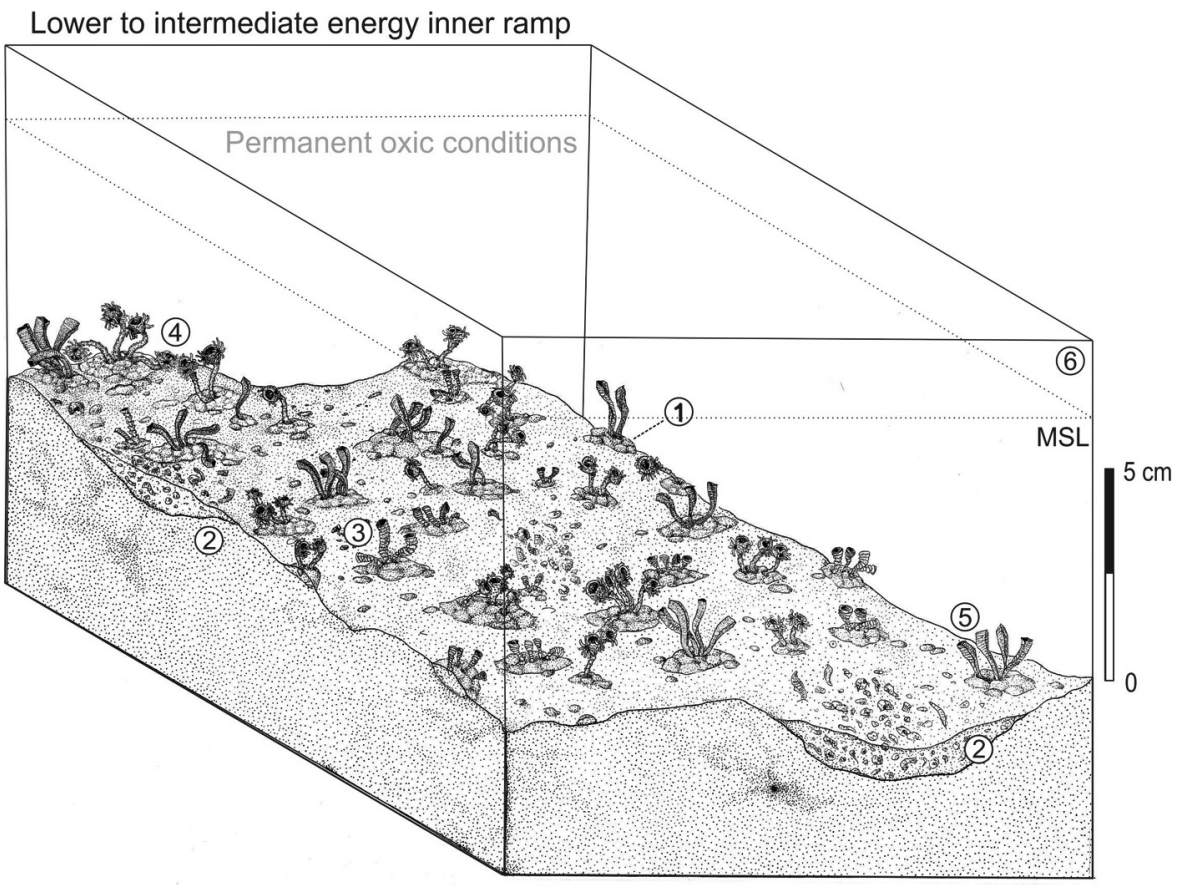

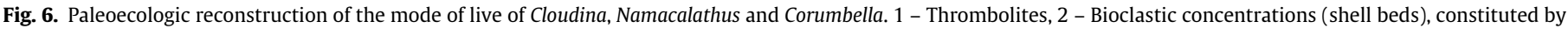

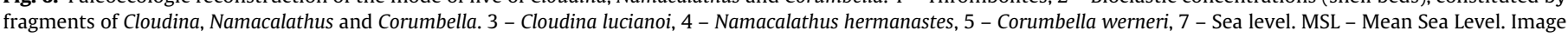

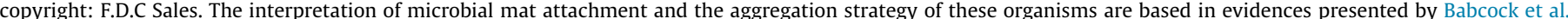

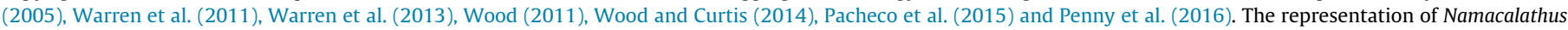

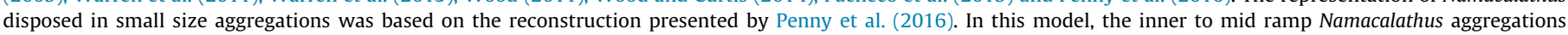
apparently have a lower density of individuals than those found in the mid to outer ramp settings.

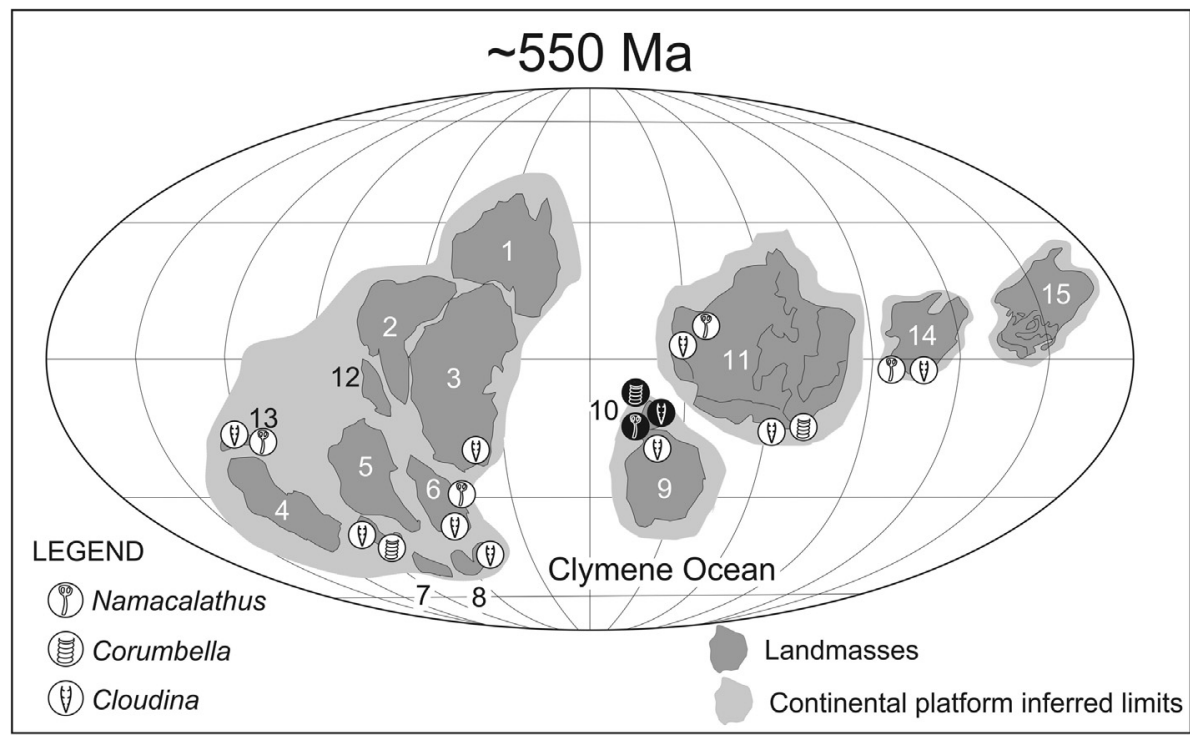

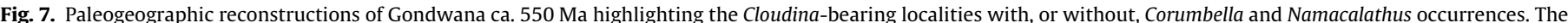

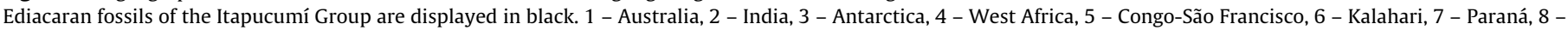

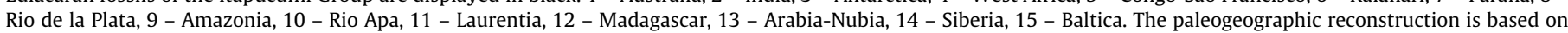

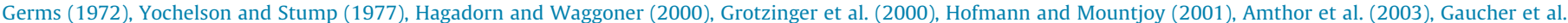
(2003), Trindade et al. (2006), Li et al. (2008), Kontorovich et al. (2008), Warren et al. (2011), and Tohver et al. (2012).

low latitudes areas (restricted to the paleo Equator, $30^{\circ}$ north and $30^{\circ}$ south, see Fig. 7) also indicate the preference of this organism for warm waters. On the other hand, Cloudina was recorded in cool water deposits and cold inner platforms, as in the southern Proto-
Gondwana supercontinent (Cloudina in Rio de La Plata craton, Fig. 7), suggesting adaptation to these environments.

The worldwide distribution of Namacalathus indicates that this genus can be considered as a guide fossil for the terminal Ediacaran 
Period, broadly coincident with the Cloudina Range Zone (Gaucher and Germs, 2009), although somewhat restricted to warm waters.

\section{Final remarks}

Namacalathus from Paraguay is a metazoan with simple although unusual morphology, characterized by a hollow stem with a cup attached in its apical portion (for detailed reconstructions see Fig. 6). Namacalathus described in the Nama Group (Namibia) has a goblet with spheroidal shape marked by a hole in the upper portion and six or seven small side lumens (apertures), which are not always preserved. This genus is considerably larger than Cloudina: whereas the latter rarely exceeds $20 \mathrm{~mm}$ in length (Germs, 1972), Namacalathus (stem and cup), commonly exceeds $50 \mathrm{~mm}$ (Grotzinger et al., 2000). With the notable exception of the Nama Group deposits, Namacalathus is usually less abundant than Cloudina bioclasts, comprising aggregates and clusters of fragmented specimens encompassed by (or between) densely-packed Cloudina concentrations and thrombolite domes (Hofmann and Mountjoy, 2001; Amthor et al., 2003; Kontorovich et al., 2008).

Based on known occurrences of Cloudina and Namacalathus and their abundances it is clear that the first was the premier ecological engineer in reef building. In other words, in the context of the first metazoan reefs of Earth's history, Namacalathus figures as an illustrious supporting actor. Finally, as interpreted by Penny et al. (2014, 2016), Cloudina and Namacalathus were the first skeletal animals to promote mutual attachment, confirming that the advent of reef-building organism occurred $\sim 20$ Myr before the archaeocyaths in the Lower Cambrian. Together with the newly formed metazoan reefs, the appearance of the biomineralized skeletons (i.e., bioclasts) in the Ediacaran was the ecological novelty that marks the birth of the Phanerozoic-style of shallow marine substrates. Finally, the newly described association of calcified Namacalathus and the organic-walled Corumbella werneri in Paraguay provides an opportunity to understand how and why the epibenthic animals in the Ediacaran seas used different strategies to perform the skeletogenesis.

\section{Acknowledgments}

The authors thank FAPESP (Grants 2010/19584-4; 2010/026770, 2015/24608-3), CNPq (Grants 490234/2005-4 and 444070/20141) and PROPE - UNESP for funding; Viceministerio de Minas y Energía de Paraguay and Industria Nacional del Cemento, specially the geologist Alberto Arias Caceres, for support during the field work. This work was made with institutional support of the São Paulo State University. The editor and two anonymous reviewers offered constructive criticism and detailed reviews of the manuscript, and are acknowledged. We also thank to Felipe Daniel de Castro Sales for the illustrations represented in Figs. 5 and 6. L.V. Warren, M.G. Simões, C. Riccomini, P.C. Boggiani, and A.N. Sial are fellows of the CNPq.

\section{References}

Amthor, J.E., Grotzinger, J.P., Schröder, S., Bowring, S.A., Ramezani, J., Martin, M.W., Matter, A., 2003. Extinction of Cloudina and Namacalathus at the PrecambrianCambrian boundary in Oman. Geology 31, 431-434.

Babcock, L.E., Grunow, A.M., Sadowski, G.R., Leslie, S.A., 2005. Corumbella, an Ediacaran grade organism from the Late Neoproterozoic of Brazil. Palaeogeogr. Palaeoclimatol. Palaeoecol. 220, 7-18.

Bengtson, S., 1994. The advent of animal skeletons. In: Bengston, S. (Ed.), Early Life on Earth: Nobel Symposium 84. Columbia University Press, New York, pp. 412 425.

Bengtson, S., 2002. Origins and early evolution of predation, in: Kowalewski, M., Kelley, P. H. (Eds.), The fossil record of predation. The Paleontological Society Papers 8. The Paleontological Society, pp. 289-317.
Bengtson, S., 2004. Early skeletal fossils, in: Lipps, H., Wagooner, B.M. (Eds.), Neoproterozoic-Cambrian Biological Revolutions. The Paleontological Society Papers 10. The Paleontological Society, pp. 67-77.

Boggiani, P.C., Gaucher, C., Sial, A.N., Babinski, M., Simona, C.M., Riccomini, C., Ferreira, V.P., Fairchild, T.R., 2010. Chemostratigraphy of the Tamengo Formation (Corumbá Group, Brazil): a contribution to the calibration of the Ediacaran carbon-isotope curve. Precam. Res. 182, 382-401.

Campanha, G.A.C., Warren, L.V., Boggiani, P.C., Grohmann, C.H., Cáceres, A.A., 2010 Structural analysis of the Itapucumí Group in the Vallemí region, northern Paraguay: evidence of a newBrasiliano /Pan-African mobile belt. J. S. Am. Earth Sci. 30, 1-11.

Debrenne, F., 2007. Lower Cambrian archaeocyathan bioconstructions. C.R. Palevol 6, 5-19.

Gaucher, C., Germs, G.J.B., 2009. Skeletonised metazoans and protists Neoproterozoic-Cambrian biota. In: Gaucher, C., Sial, A.N., Halverson, G.P., Frimmel, H.E. (Eds.), Neoproterozoic-Cambrian Tectonics, Global Change and Evolution: A Focus on Southwestern Gondwana. Elsevier, Amsterdam, pp. 327338.

Gaucher, C., Boggiani, P.C., Sprechmann, P., Sial, A.N., Fairchild, T., 2003. Integrated correlation of the Vendian to Cambrian Arroyo del Soldado and Corumbá Groups (Uruguay and Brazil): palaeogeographic, palaeoclimatic and palaeobiologic implications. Precambr. Res. 120, 241-278.

Germs, G.J.B., 1972. New shelly fossils from Nama Group, South West Africa. Am. J. Sci. 272, 752-761.

Gómez-Peral, L.E., Poiré, G.D., Strauss, H., Zimmermann, U., 2007 Chemostratigraphy and diagenetic constraints on Neoproterozoic carbonate successions from the Sierras Bayas Group, Tandilia System, Argentina. Chem. Geol. 237, 109-128.

Grotzinger, J.P., Bowring, S.A., Saylor, B.Z., Kaufman, A.J., 1995. Biostratigraphic and geochronologic constraints on early animal evolution. Science 270, 598-604.

Grotzinger, J.P., Watters, W.A., Knoll, A.H., 2000. Calcified metazoans in thrombolite stromatolite reefs of the terminal Proterozoic Nama Group, Namibia. Paleobiology 26, 334-359.

Hagadorn, J.W., Waggoner, B., 2000. Ediacaran fossils from the southwestern Great Basin, United States. J. Paleontol. 74, 349-359.

Hofmann, H.J., Mountjoy, E.W., 2001. Namacalathus-Cloudina assemblage in Neoproterozoic Miette Group (Byng Formation), British Columbia: Canada's oldest shelly fossils. Geology 29, 1091-1094.

Hua, H., Chen, Z., Yuan, X., 2007. The advent of mineralized skeletons in Neoproterozoic Metazoa - New fossil evidence from the Gaojiashan Fauna. Geol. J. 45, 263-279.

Knoll, A.H., 2003. Biomineralization and evolutionary history. Rev. Mineral Geochem. 54, 329-356.

Kontorovich, A.E., Varlamov, A.I., Grazhdankin, D.V., Karlova, G.A., Klets, A.G. Kontorovich, V.A., Saraev, S.V., Terleev, A.A., Belyaev, S.Yu., Varaksina, I.V. Efimov, A.S., Kochnev, B.B., Nagovitsin, K.E., Postnikov, A.A., Filippov, Yu.F., 2008 A section of Vendian in the east of West Siberian Plate (based on data from the Borehole Vostok 3). Russ. Geol. Geophys. 49, 932-939.

Li, Z.X., Bogdanova, S.V., Collins, A.S., Davidson, A., De Waele, B., Ernst, R.E., Fitzsimons, I.C.W., Fuck, R.A., Gladkochub, D.P., Jacobs, J., Karlstrom, K.E., Lu, S., Natapov, L.M., Pease, V., Pisarevsky, S.A., Thrane, K., Vernikovsky, V., 2008. Assembly, configuration, and break-up history of Rodinia: a synthesis. Precambr. Res. 160, 179-210.

Lowenstam, H.A., Weiner, S., 1989. On Biomineralization. Oxford University Press, New York.

Pacheco, M.L.A.F., Galante, D., Rodrigues, F., Leme, J.M., Bidola, P., Hagadorn, W. Stockmar, M., Herzen, J., Rudnitzki, I.D., Pfeiffer, F., Marques, A.C., 2015. Insights into the skeletonization, lifestyle, and affinity of the unusual Ediacaran fossil Corumbella. PlosOne 10 (3), e0114219.

Penny, A.M., Wood, R., Curtis, A., Bowyer, F., Tostevin, R., Hoffman, K.H., 2014. Ediacaran metazoan reefs from the Nama Group, Namibia. Science 344, 1504 1506.

Penny, A.M., Wood, R., Zhuravlev, A.Y., Curtis, A., Bowyer, F., Tostevin, R., 2016 Intraspecific variation in an Ediacaran skeletal metazoan: Namacalathus from the Nama Group, Namibia. Geobiology 15 (1), 81-93.

Pratt, B.R., 1982. Stromatolite decline - a reconsideration. Geology 10, 512-515.

Thunell, R.C., Williams, D.F., Howell, M., 1987. Atlantic - Mediterranean water exchange during the late Neogene. Paleoceanography 2, 661-678.

Tohver, E., Cawood, P.A., Rossello, E.A., Jourdan, F., 2012. Closure of the Clymene Ocean and formation of West Gondwana in the Cambrian: evidence from the Sierras Australes of the southernmost Rio de la Plata craton, Argentina. Gondwana Res. 21, 394-405.

Trindade, R.I.F., D'agrella-Filho, M.S., Epof, I., Neves, B.B.B., 2006. Paleomagnetism of Early Cambrian Itabaiana mafic dikes (NE Brazil) and the final assembly of Gondwana. Earth and Planetary Science Letters 244, 361-377.

Van Iten, H., Marques, A.C., Leme, J.M., Pacheco, M.L.A.F., Simões, M.G., 2014. Origin and early diversification of the phylum Cnidaria Verrill: major developments in the analysis of the taxon's Proterozoic-Cambrian history. Palaeontology 57, 677-690.

Vinn, O., Zatón, M., 2012. Inconsistencies in proposed annelid affinities of early biomineralized. Organism Cloudina (Ediacaran): structural and ontogenetic evidences. Carnets de Geologie 39-47 (CG2012_A03).

Warren, L.W., 2011. Tectônica e Sedimentação do Grupo Itapucumi (Ediacarano, Paraguay Setentrional). Ph.D. Thesis, University of São Paulo, Brazil, pp. 215.

Warren, L.V., Fairchild, T.R., Gaucher, C., Boggiani, P.C., Poiré, D.G., Anelli, L.E. Inchausti. J.C.G., 2011. Corumbella and in situ Cloudina in association with 
thrombolites in the Ediacaran Itapucumi Group, Paraguay. Terra Nova 23, 382389.

Warren, L.W., Pacheco, M.L.A.F., Fairchild, T.R., Simões, M.G., Riccomini, C., Boggiani, P.C., Cáceres, A.A., 2012. The dawn of animal skeletogenesis: ultrastructural analysis of the Ediacaran metazoan Corumbella werneri. Geology 40 (8), 691694.

Warren, L.V., Simões, M.G., Fairchild, T.R., Riccomini, C., Gaucher, C., Anelli, L.E., Freitas, B.T., Boggiani, P.C., Quaglio, F., 2013. Environmental impact of the oldest metazoan bioclastic sediments. Geology 41, 507-510.

Watters, W.A., Grotzinger, J.P., Knoll, A.H., 2000. Calcified metazoans in thrombolite-stromatolite reefs of the terminal Proterozoic Nama Group, Namibia. Paleobiology 26, 334-359.

Wood, R.A., Grotzinger, J.P., Dickson, J.A.D., 2002. Proterozoic modular biomineralized metazoan from the Nama Group, Namibia. Science 296, $2383-$ 2386.

Wood, R.A., 2011. Paleoecology of the earliest skeletal metazoan communities: implications for early biomineralization. Earth Sci. Rev. 106, 184-190.

Wood, R., Zhuravlev, A.Y., 2012. Escalation and ecological selectively of mineralogy in the Cambrian Radiation of skeletons. Earth Sci. Rev. 115, 249-261.
Wood, R.A., Curtis, A., 2014. Extensive metazoan reefs from the Ediacaran Nama Group, Namibia: the rise of benthic suspension feeding. Geobiology 13 (2), 112122.

Wood, R., Zhuravlev, A.Y., Sukhov, S.S., Zhu, M., Zhao, F., 2016. Demise of Ediacaran dolomitic seas marks widespread biomineralization on the Siberian Platform. Geology 45, 27-30.

Wood, R., Curtis, A., Penny, A., Zhuravlev, A.Y., Curtis-Walcott, S., Iipinge, S., Bowyer, F., 2017. Flexible and responsive growth strategy of the Ediacaran skeletal Cloudina from the Nama Group, Namibia. Geology 45, 259-262.

Yochelson, E.L., Stump, E., 1977. Discovery of Early Cambrian fossils at Taylor Nunatak, Antarctica. J. Paleontol. 51, 872-875.

Zhou, C., Xiao, S., 2007. Ediacaran $\mathrm{d}^{13} \mathrm{C}$ chemostratigraphy of South China. Chem. Geol. 237, 89-108.

Zhuravlev, A., Wood, R., 2008. Eve of biomineralization: Controls on skeletal mineralogy. Geology 36 (12), 923-926.

Zhuravlev, A.Y., Wood, R.A., Penny, A.M., 2015. Ediacaran skeletal metazoan interpreted as a lophophorate. Proc. R. Soc. 282, 20151860. 